\title{
Pengaruh Self Efficacy dan Pendidikan Ekonomi di Keluarga terhadap Minat Berwirausaha melalui Internalisasi Nilai Kewirausahaan pada Mahasiswa Fakultas Pendidikan Ilmu Sosial dan Homaniora IKIP Budi Utomo Malang.
}

\author{
Trio Andi Cahyono \\ Program Studi Pendidikan Ekonomi dan Kewirausahaan IKIP Budi Utomo \\ Jalan Citandui 46 Malang \\ Puspita Pebri Setiani \\ Program Studi Pendidikan Sejarah dan Sosiologi IKIP Budi Utomo Malang \\ Jalan Citandui 46 Malang
}

\begin{abstract}
The labor force based on BPS in 2013 as many as 121.19 million, while 114.02 million people already working then there are 11.90 million people into unemployment status. Entrepreneurial role is not only limited to the development of the nation's economy, but also as a driver, controller and user of a nation's economy. This research is an explanatory research or explanatory research, designed with a quantitative approach. Results of this study found that: (1) Self-efficacy does not affect the interest in entrepreneurship. The factors that cause insignificant is the attitude and habits that are owned by each student is not good. (2) Education in the family economy does not affect the interest in entrepreneurship. The factors that cause insignificant was socializing outside the home where a lot of interest in entrepreneurship is formed from outside the home. Additionally insignificant jiga was caused by the scarcity of personal communication or discussion between family members who discuss cases with material economic terkail economy. (3) Internalization of entrepreneurial values affect the interest in entrepreneurship. Internalization of self entrepreneurship can instill an attitude or behavior to become an entrepreneur. (4) Self-efficacy indirect effect of the interest in entrepreneurship through the internalization of entrepreneurship. Self-efficacy will form the internalization of entrepreneurship that will ultimately affect their interest in entrepreneurship. (5) Education in the family economy indirect effect of the interest in entrepreneurship through the internalization of entrepreneurship.
\end{abstract}

Keywords: self-efficacy, economic education in the family, internalization of entrepreneurship and entrepreneurial interests.

Tingkat pengangguran pada umur 15 tahun keatas di Indonesia berdasarkan data BPS pada tahun 2012 menunjukkan angka 6.1\% sedangkan pada tahun 2013 menunjukkan angka $6.2 \%$ dimana Indonesia menjadi Negara urutan 17 dengan pengangguran tertinggi di dunia. Presentasi pengangguran pada tahun 2013 yang meningkat dari presentasi pengangguran tahun 2012 menunjukkan masih besarnya pekerjaan rumah pemerintah dalam menyediakan lapangan pekerjaan terutama bagi lulusan sarjana yang sudah memasuki angkatan kerja yang membutuhkan lapangan pekerjaan lebih besar karena jumlah pengangguran sarjana akan menjadi lebih besar ketika lapangan 
pekerjaan tidak ada peningkatan pada setiap tahunnya.

Jumlah angkatan kerja berdasarkan data BPS pada tahun 2013 sebanyak 121.19 juta orang, sedangkan 114.02 juta orang sudah bekerja maka terdapat 11.90 juta orang dalam status pengangguran. Pengangguran akan menjadi masalah yang kompleks ketika Indonesia memasuki masa free trade area, MEA dan AFTA sehingga dibutuhkan SDM yang mampu bersaing dan menghadapi persaingan dunia. Penganggu-ran akan semakin meningkat apabila skill SDM Indonesia tidak mampu bersaing dengan kemajuan global.

Minat merupakan salah satu faktor psikologis yang mendorong seseorang dalam mencapai tujuan. Bagaimana orang bertingkah laku dalam situasi tertentu tergantung pada lingkungan dan kondisi kognitif.Khususnya faktor kognitif yang berhubungan dengan keyakinan bahwa dia mampu atau tidak mampu melakukan tindakan yang memuaskan. Bandura (1997) menyebut keyakinan atau harapan diri ini sebagai efikasi diri dan harapan hasilnya disebut ekspektasi hasil. Efikasi diri merupakan kepercayaan seseorang atas kemampuan dirinya untuk menyelesaikan pekerjaan. Dalam kaitannya dengan kewirausahaan, peranan efikasi diri sangatlah besar. Seseorang dengan tingkat efikasi diri yang tinggi cenderung memiliki motivasi yang kuat untuk berwirausaha. Keyakinan ini berjalan bersama dengan minat untuk berwirausaha.Hal ini sesuai dengan pendapat Bandura (1997) yang mengatakan bahwa efikasi diri merupakan komponen yang penting dalam memberikan kontribusi yang besar terhadap usaha seseorang, minat dan ketekunannya.

Melalui lingkungan keluarga, anak mulai belajar mengenal uang dan cara memperolehnya serta pemanfaatannya, memperoleh pengetahuan dan pengalaman dari cara mendapatkan barang dan jasa melalui proses jual beli, belajar hidup hemat, membiasakan diri untuk menabung dan sebagainya. Keluarga menjadi contoh yang sangat baik bagi anak. Misalkan tentang pekerjaan orang tua,apabila orang tuanya seorang pengusaha maka anak tersebut akan selalu memperhatikan kebiasaan orang tua dan kiat-kiat dalam melakukan pekerjaannya agar sukses. Hal kecil tersebut bisa memberikan rangsangan untuk anak tersebut berminat melakukan pekerjaan yang sama seperti orang tuanya yaitu melakukan wirausaha.

Pengukuran minat berwirausaha dapat dilakukan dengan mengetahui berbagai informasi mengenai objek minat (berwirausaha), adanya partisipasi dan dorongan jiwa untuk berusaha mengambil langkah kearah wirausaha, adanya kemauan dan hasrat untuk berwirausaha (Shaleh, 2004). Jadi, informasi mengenai objek minat dalam berwirausaha (misal, dalam pemilihan wirausaha yang cocok dalam lingkungan tertentu dan berbagi informasi dalam bidang wirausaha). Dorongan jiwa yang kuat untuk berwirausaha. Misalnya seseorang ingin melakukan wirausaha karena dorongan dari diri sendiri. Hasrat ingin berwirausaha muncul karena keinginan diri sendiri,dorongan dari keluarga dan pengetahuan yang telah dimiliki.

Self efficacy merupakan keyakinan diri yang memiliki tiga dimensi yaitu magnitude, streght dan generality yang dalam hal berwirausaha terdapat beberapa indikator yaitu: (a) keyakinan untuk mengatasi resiko dalam berwirausaha; (b) kemampuan menghadapi kesulitan; (c) keyakinan dan kemampuan berwirausaha; (d) kepercayaan pada kemampuan diri sendiri; (e) luas bidang wirausaha yang diminati, serta (f) keyakinan dan kemantapan seseorang yang akan berlaku dalam berbagai macam aktivitas dan situasi.

Pendidikan ekonomi di keluarga merupakan persepsi siswa tentang proses pembelajaran di lingkungan keluarga, dalam hal ini lebih ditekankan pada pembelajaran 
keuangan dilingkungan keluarga dan penanaman sikap berwirausaha. Sosialisasi keuangan ataupun penanaman nilai berwirausaha yang dilakukan oleh orang tua yang mempunyai pekerjaan sebagai wirausahawan menjadi contoh bagi anakanaknya. Maka dari itu yang menjadi ukuran variabel ini yaitu (a) keteladanan, (b) penjelasan verbal, (c) tuntutan perilaku yang relevan. Menurut Alwisol (2011: 287), "efikasi diri adalah persepsi diri sendiri mengenai seberapa bagus diri dapat berfungsi dalam situasi tertentu. Efikasi diri berhubungan dengan keyakinan bahwa diri memiliki kemampuan melakukan tindakan yang diharapkan".Efikasi diri berbeda dengan citacita karena cita-cita menggambarkan sesuatu yang ideal yang seharusnya dapat dicapai, sedangkan efikasi menggambarkan penilaian kemampuan diri.

Intensitas internalisasi nilai kewirausahaan yaitu seberapa sering atau dapat dikatakan kegigihan mahasiswa dalam menerapkan nilai-nilai kewirausahaan dalam kehidupan sehari-hari. Nilai kewirausahaan antara lain yaitu: (a) percaya diri; (b) berorientasi tugas dan hasil; (c) keberanian mengambil resiko; (d) kepemimpinan; (e) berorientasi ke masa depan, dan (f) kretif dan inovatif. Intensitas adalah kemampuan/ kekuatan, gigih tidaknya, kehebatan. Sedangkan dalam kamus psikologi, intensitas adalah kuatnya tingkah laku atau pengalaman atau sikap yang dipertahankan (Anshari, 1996:297)

Minat berwirausaha dalam penilitian ini mengandung tiga aspek yaitu kognisi, emosi dan konasi,yang didalamnya terdapat beberapa indikator antara lain: (a) mengetahui berbagai informasi mengenai objek minat (berwirausaha); (b) adanya partisipasi dan dorongan jiwa untuk berusaha mengambil langkah kearah wirausaha, serta (c) adanya kemauan dan hasrat untuk berwirausaha. Alma (2007) menyatakan terdapat tiga faktor kritis yang berperan dalam minat berwirausaha tersebut yaitu personal, sociological dan environmental

\section{METODE}

Penelitian yang dilakukan ini merupakan penelitian penjelasan atau explanatory research yaitu penelitian yang menjelaskan hubungan kausal antara variabelvariabel melalui pengujian hipotesis pada data yang sama. Sedangkan berdasarkan tingkat eksplanasi atau penjelasan, penelitian yang digunakan adalah penelitian assosiatif yaitu penelitian yang bertujuan untuk mengetahui hubungan atau pengaruh dua variabel atau lebih. Penelitian ini dirancang dengan pendekatan kuantitatif.

Keterangan :

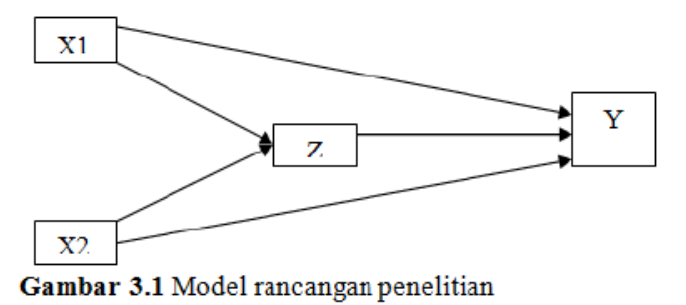

HASIL DAN PEMBAHASAN

\section{A. Pengaruh Self Efficacy terhadap Minat} Berwirausaha

Diketahui nilai Standardized Coefecient/ Beta adalah -0,05 dan nilai sig 0,435. Hasil
$\mathrm{X} 1=$ self efficacy

$\mathrm{X} 2=$ pendidikan ekonomi di keluarga

$=$ internalisasi nilai kewirausahaan

$=$ minat berwirausaha

tersebut menunjukkan bahwa nilai sig lebih besar dari 0,05 . Sehingga dapat disimpulkan bahwa $\mathrm{H} 0$ yang berbunyi "Tidak ada pengaruh yang signifikan antara self efficacy terhadap minat berwirausaha mahasiswa Fakultas 
Pendidikan Ilmu Sosial dan Humaniora IKIP Budi Utomo Malang" diterima, dan Ha yang berbunyi "Ada pengaruh yang signifikan self efficacy terhadap minat berwirausaha mahasiswa Fakultas Pendidikan Ilmu Sosial dan Humaniora IKIP Budi Utomo Malang" ditolak.

Artinya jika self efficacy yang dimiliki oleh mahasiswa bertambah baik dari sisi kualitas maka tidak mempengaruhi minat berwirausaha secara signifikan. Jadi ketika suatu efikasi diri bertambah baik maka tidak berpengaruh terhadap minat berwirausaha secara siknifikan karena efikasi diri yang dimiliki seseorang berbeda-beda. Sehingga efikasi diri yang baik dan ditingkatkan lagi maka dampaknya tidak terlihat, dan jika efikasi diri kurang baik dan diperbaiki maka untuk merubah sikap dan kebiasaan maka waktu yang singkat tidaklah cukup artinya secara langsung tidak mempengaruhi.

\section{B. Pengaruh Pendidikan Ekonomi di Keluarga terhadap Minat Berwirausaha} Didapatkan nilai Standardized Coefecient/ Beta adalah 0,048 dan nilai sig 0,475.Hasil tersebut menunjukkan bahwa sig lebih besar dari 0.05. sehingga dapat disimpulkan bahwa $\mathrm{H} 0$ yang berbunyi "tidak ada pengaruh signifikan pendidikan ekonomi dikeluarga terhadap minat berwirausaha mahasiswa Fakultas Pendidikan Ilmu Sosial dan Humaniora IKIP Budi Utomo Malang" diterima, dan Ha yang berbunyi "ada pengaruh signifikan pendidikan ekonomi di keluarga terhadap minat berwirausaha mahasiswa Fakultas Pendidikan Ilmu Sosial IKIP Budi Utomo Malang" ditolak.

Artinya jika lingkungan keluarga bertambah baik satu tingkat maka tidak mempengaruhi minat untuk berwirausaha secara signifikan. Jika ketika suatu lingkungan bertambah baik maka tidak berpengaruh terhadap minat berwirausaha secara signifikan karena sikap yang dibentuk oleh keluarga dalam bentuk kebiasaan telah membentuk kepribadian seseorang. Sehingga jika sudah baik dan lebih ditingkatkan lagi maka dampaknya akan terlihat, dan jika lingkungan kurang baik dan diperbaiki maka untuk merubah kepribadian dan kebiasaan, waktu yang singkat tidaklah cukup artinya secara langsung tidak mempengaruhi. Dengan demikian dapat disimpulkan bahwa tidak ada pengaruh yang signifikan pendidikan ekonomi di keluarga terhadap minat berwirausaha mahasiswa Fakultas Pendidikan Ilmu Sosial dan Humaniora IKIP Budi Utomo Malang.

\section{Pengaruh Internalisasi Nilai Kewirausahaan terhadap Minat Berwirausaha}

Didapatkan nilai Standardized Coefecient/ Beta adalah 0,336 dan nilai sig 0,000 . Hasil tersebut menunjukkan bahwa signifikansi lebih kecil dari 0,05. Maka dapat disimpulkan bahwa H0 yang berbunyi "tidak ada pengaruh yang signifikan internalisasi nilai kewirausahaan terhadap minat berwirausaha mahasiswa Fakultas Pendidikan Ilmu Sosial dan Humaniora IKIP Budi Utomo Malang" ditolak dan Ha yang berbunyi "Ada pengaruh signifikan internalisasi nilai kewirausahaan terhadap minat berwirausaha" diterima.

Artinya jika internalisasi nilai-nilai kewirausahaan dinaikkan, maka minat untuk berwirausaha akan meningkat menjadi seorang wirausaha. Penanaman nilai-nilai berwirausaha yang baik akan mempengaruhi perilaku seseorang yang semakin baik. Penanaman nilai kewirausahaan memiliki dampak selayaknya seperti motivasi, maka jika internalisasi nilainilai kewirausahaan seseorang itu tinggi maka minat untuk melakukan menjadi seorang wirausaha akan tinggi. Dengan demikian dapat disimpulkan bahwa ada pengaruh positif yang signifikan internalisasi nilai kewirausahaan terhadap minat berwirausaha mahasiswa 
Fakultas Pendidikan Ilmu Sosial dan Humaniora IKIP Budi Utomo Malang.

Berdasarkan hasil analisis data yang sudah diuraikan, terdapat bukti bahwa self efficacy tidak berpengaruh secara signifikan terhadap minat berwirausaha. Hasil tersebut menunjukkan bahwa self efficacy yang tinggi tidak mempengaruhi minat berwirausaha. Hal ini bertolak belakang dengan pendapat Alma (2007) yang menyatakan bahwa terdapat tiga faktor yang berperan dalam minat berwirausaha. Faktor tersebut adalah personal, sociological dan environmental. Pada faktor personal terdapat self efficacy yang mana berpengaruh terhadap minat berwirausaha. Hal ini dibuktikan dengan pembagian angket yang di sebarkan kepada mahasiswa yang setelah di analisis tidak terdapat hubungan yang signifikam. Akan tetapi perlu dilakukan pengkajian kembali untuk memantapkan apakah self efficacy tidak berpengaruh terhadap minat berwirausaha.

Selanjutnya dari hasil temuan yang sudah diuraikan sebelumnya, mengungkapkan bahwa pendidikan ekonomi di keluarga tidak berpengaruh dengan minat berwirausaha. Hal ini bertentangan dengan pendapat Hal ini bertentangan dengan apa yang diungkapkan Antunez (2000) yang menyatakan bahwa orang tua merupakan guru pertama seorang anak, dan memainkan peran penting di seluruh pendidikan formal. Hasil penelitian ini berbeda dengan pendapat Alma (2007) yang menyatakan bahwa keluarga sangat berperan aktif dalam menumbuhkan dan mempercepat untuk menjadi seorang wirausahawan. Pada keluarga dilakukan penamaman minat, sikap dan perilaku untuk berwirausaha. Pada pengujian ini di ketahui bahwa keluarga tidak mempengaruhi minat berwirausaha secara langsung. Faktor yang menjadi penyebab ketidaksignifikanan mungkin adalah sosialisasi banyak dilakukan diluar rumah.

Selanjutnya hasil penelitian menunjukkan bahwa ada pengaruh positif dan signifikan antara internalisasi nilai-nilai kewirausahaan dan minat berwirausaha. Internalisasi nilai-nilai kewirausahaan yang tinggi akan berdampak pada minat berwirausaha seseorang. Seseorang yang menanamkan nilai berwirausaha terhadap dirinya akan nampak pada perilakunya. Internalisasi nilai kewirausahaan akan mempengaruhi minat berwirausaha secara berkelanjutan. Oleh karena itu internalisasi nilai-nilai kewirausahaan merupakan prediktor dari minat berwirausaha.

\section{KESIMPULAN DAN SARAN}

Berdasarkan hasil analisis dan pembahasan dapat disimpulkan sebagai berikut:

Self efficacy tidak berpengaruh terhadap minat berwirausaha mahasiswa Fakultas Pendidikan Ilmu Sosial dan Humaniora IKIP Budi Utomo Malang. Hal ini dikarenakan karena keyakinan seorang mahasiswa yang beranekaragam sehingga mahasiswa mempunyai tingkat keragu-raguan yang sangat tinggi apabila ingin melakukan sesuatu khususnya untuk melakukan kegiatan berwirausaha.

Pendidikan ekonomi di keluarga tidak berpengaruh terhadap minat berwirausaha mahasiswa Fakultas Pendidikan Ilmu Sosial dan Humaniora IKIP Budi Utomo Malang. Faktor yang menjadi penyebab ketidaksignifikanan adalah sosialisasi banyak dilakukan di luar rumah. Oleh sebab itu pengaruh terhadap minat berwirausaha mahasiswa dimungkinkan terbentuk dari luar lingkungan keluarga. Selain itu, ketidaksignifikanan juga disebabkan oleh faktor jarangnya komunikasi atau diskusi antar anggota keluarga yang membahas tentang kasus-kasus ekonomi yang terkait dengan materi ekonomi.

Internalisasi nilai-nilai kewirausa-haan berpengaruh terhadap minat berwirausaha 
mahasiswa Fakultas Pendidikan Ilmu Sosial dan Humaniora IKIP Budi Utomo Malang. Internalisasi nlai-nilai kewirausahaan menggerakkan seseorang untuk memiliki minat berwirausaha. Semakin tinggi internalisasi nilai-nilai kewirausahaan maka minat berwirausaha akan semakin baik, dan sebaliknya jika internalisasi nilai kewirausahaan rendah maka hal itu akan berdampak terhadap minat mereka. Self efficacy berpengaruh secara tidak langsung terhadap minat berwirausaha melaui internalisasi nilai-nilai kewirausa-haan mahasiswa Fakultas Pendidikan Ilmu Sosial dan Humaniora IKIP Budi Utomo Malang. Self efficacy yang baik akan membentuk internalisasi nilai-nilai kewirausahaan yang pada akhirnya akan mempengaruhi minat berwirausaha mereka. Jika self efficacy baik maka baik pula minat berwirausaha dengan mediasi internalisasi nilai-nilai kewirausahaan. Bagi pendidik ekonomi disarankan untuk menanamkan dan meningkatkan minat untuk berwirausaha. Sebab dengan penanaman minat berwirausaha maka mahasiswa akan lebih tertarik dengan kegiatan berwirausaha yang nantinya akan menambah perekonomian mahasiswa tersebut. Penanaman tersebut dapat dilakukan dengan memberikan seminar atau pelatihan terkait dengan kewirausahan atau memberikan bimbingan kepada mahasiswa untuk membuat program kreativitas mahasiswa dalam bidang kewirausahaan. $\begin{array}{lll}\text { Bagi orang tua disarankan } & \text { perlu } \\ \text { melakukan diskusi, } & \text { penjelasan serta }\end{array}$ pengembangan wawasan anak-anak mereka. Karena memang dapat dipahami bahwa secara hakekat pembelajaran di lingkungan keluarga secara karakteristik berbeda dengan pembelajaran di kampus atau sekolah.

\section{DAFTAR RUJUKAN}

Alma, Buchari. 2007. Kewirausahaan untuk Mahasiswa dan Umum. Bandung: Alfabeta

Alwisol. 2011. Psikologi Kepribadian. Edisi Revisi. Universitas Muhammadiyah Malang (UMM Press): Malang

Anshari, M. Hafi. 1996. Kamus Psikologi. Surabaya: Usaha Nasional

Antunez, B. 2000. When everyone is involved: parents and communities in school reform. In framing effective practice: topic and issues in the education of english language learner (pp.53-59). Washington DC: National clearing housefor bilingual education.

Bandura, Albert. 1997. Self Efficacy: The Exercise of Control. New York: W.H. Free Mand and Company.

Shaleh, Abdul Rahman \& Wahab, Muhbib

Abdul. 2004. Psikologi Suatu Pengantar Dalam Persfektif Islam. Jakarta: Kencana 